\title{
BIOCHEMICAL GENETIC DIFFERENTIATION AMONG WILD POPULATIONS OF MILKFISH (Chanos chanos) IN INDONESIA
}

\author{
Ketut Sugama*) and Agus Prijono*)
}

\begin{abstract}
Four populations of milkfish ( ( hanos chanos) were collected $(\mathrm{N}=100)$ from coastal water of Aceh. Bali, East Java and South Sulawesi and were examined electrophoretically at 29 loci to determine the genetic variability and the population structure. Twelve loci (Adh, Aat-1. Est-1, Est-2, Gpd, Gpi-1, Gpi-2, Idh-1, Ldh-1, Mdh-1, 6-Pgd and Pgm-2) were polymorphic in at least one population. Six loci (Adh, Est-1, Est-2, Gpi-1, 6-Pgd and Pgm-2) were reliable genetic markers. The number of polymorphic loci, number of alleles per locus and heterozy gosity were $0.336,1.577$ and 0.068 respectively. These values were slightly higher than other marine fishes. Significant differences in allele frequencies were observed at more than one locus except between Bali and East Java populations. The mean Nei s genetic distance between population pairs was 0.00155 . This value is typical divergence between conspecific populations. The UPGMA cluster analysis of genetic distance revealed that the milkfish populations formed three geographical groups. The results suggest that the natural populations of milkfish in Indonesia could be devided into 3 geographical groups located in the west (Aceh), midle (Bali/ E. Java) and East (South Sulawesi) Indonesia.
\end{abstract}

KEYWORD: Chanos chanos, genetic variability, population structure

\section{INTRODUCTION}

The millkfish (Chanos chanos) is one of the most important species extensively cultured in brackishwater Indonesia ponds. Recently, this species has become more important as frozen and live bait for tuna long-line capture. The supply of milkfish fry comes mainly from the wild. High demands on the supply of fry emphasize the need for artificial propagation to supplement the supply. The technology for artificial seed production of milkfish has been developed in Gondol Research Station for Coastal Fisheries, Agency for Agriculture Research and Development, and the technology has been adopted by private hatcheries who mass produced egg and fry to supply brackishwater pond of milkfish culture (Sugama et al., 1997).

The broodstocks for seed production have been collected from several regions in the country. An understanding of milkfish population structure particularly in this region is therefore a requirement for broodstock development since the existence of subpopulations or stock, heterogeneity will necessarily influence the formulation of stocking and/or conservation practices (Macaranas et al., 1990; Taniguchi \& Sugama, 1990).

Several authors have shown that proteins and enzymes are useful genetic markers for fish in culture and breeding studies (Taniguchi et al., 1983; Sugama et al., 1992; Agenese et al., 1995;
Goudie et al.,1995). Proteins and enzymes electrophoresis is also considered to be an extremely useful technique in population genetics and is particularly powerful in identifying of genetic differentiation between populations (Allendorf \& Utter, 1979; Sumantadinata \& Taniguchi, 1982; Taniguchi \& Sugama, 1990).

Although various studies have been conducted on reproduction, larva rearing, nutrition and disease of milkfish, none study directed toward genetic improvement. Therefore, genetic studies of this species were conducted to obtain basic information on the amount of genetic variability and genetic differentiation among wild populations. Electrophoresis was used for allozyme analysis. The results may be important for the future development of millfish breeding and proper management of natural populations.

\section{MATERIALS AND METHODS}

\section{Electrophoresis}

A total of 400 milkfish, (BW: 10.0-35.8 g) were collected from the coastal waters of Aceh (sample size $n=100)$, Tuban, East Java ( $=100)$, Singaraja, Bali $(n=100)$ and Takalar, South Sulawesi $(n=100)$. Whole fish were freighted to Gondol Research Station for Coastal Fisheries, Bali, where they were held frozen at $20^{\circ} \mathrm{C}$ until electrophoresed.

\footnotetext{
*) Researcher of Research Station for Coastal Fisheries, (uondol
} 


\section{K. Sugama and A. Prijono}

Four tissues (skeletal muscle, liver, heart and eye) were dissected, tissue extracts were prepared and starch gel electrophoresis was performed following the methods of Sugama et al. (1996). Fifteen enzymes and protein system were evaluated (Table 1). The staining procedures followed the method of Show \& Prasad (1970). Two buffer systems Tris-citric acid pH-8 (TC-8) and (citric acid $\mathrm{N}$-(3-Amino propylmorpholine $\mathrm{pH}: 6$ (CAMP-6) were used. Extracts from all four tissues (skeletal muscle, heart, liver and eye) were tested on all combination of buffer systems and stained in the search for optimal electrophoretic activity and resolution. The list of enzymes and proteins examined, tissue specificity, locus detected and buffer systems giving clearest resolution are given in Table 1 . A capitalized abbreviation represents each enzyme. The same abbreviation with only the first letter capitalized represents the locus coding for that enzyme. When multiple loci code for an enzyme, the locus with the most anodal migration is designated one, the next two and so on. Allelic variant are designated according to their relative mobility. The most common alleles is designated 100 and other alleles are given numbers that indicate their mobility relative to that of the common allele. Cathodal systems are designated in a similar way but given a negative sign (Shaklee et al., 1990) (Table 2).

Table 1. List of enzymes and other proteins examined, locus detected, tissue assayed, buffer

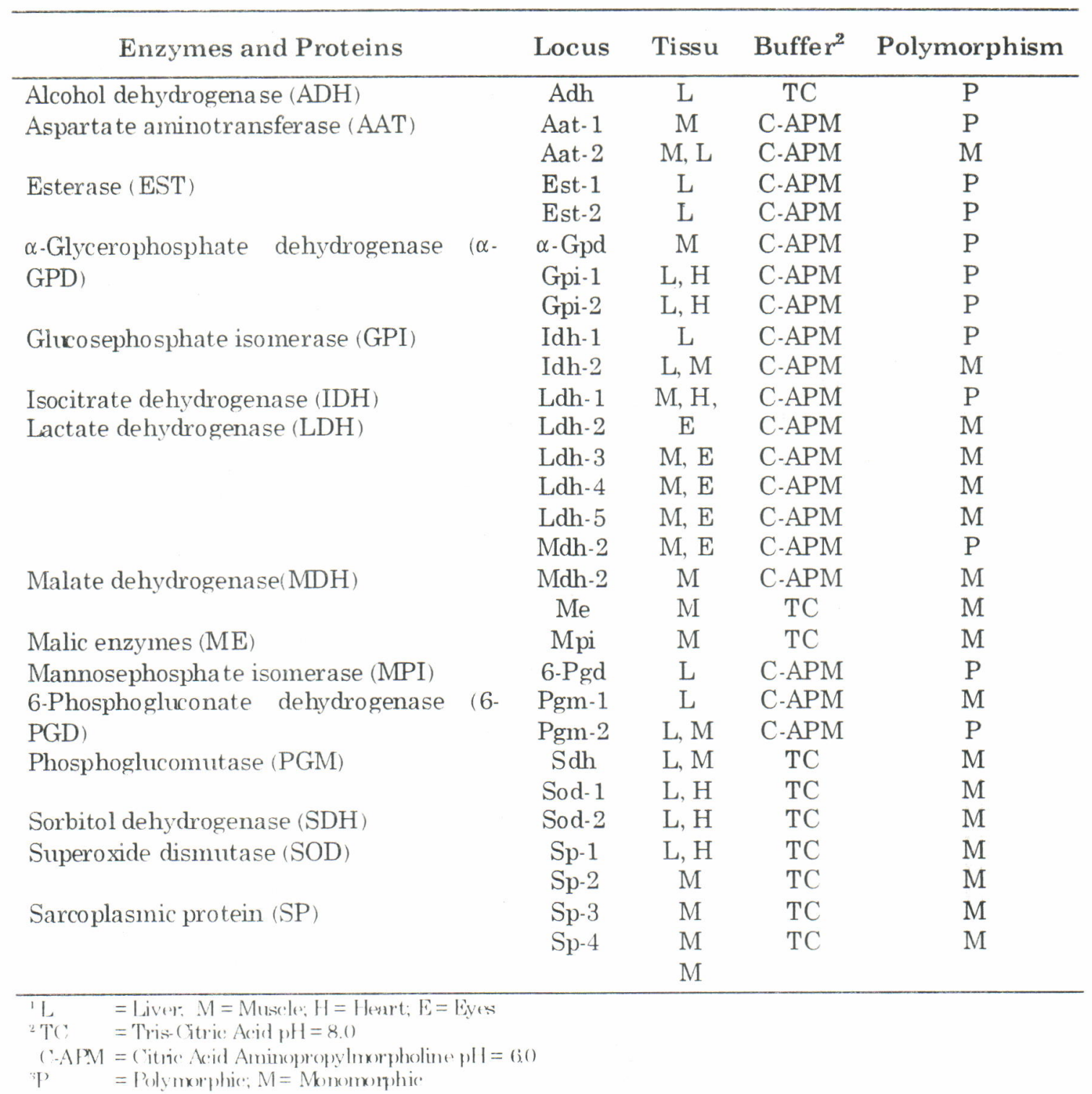


Table 2. Allele frequencies of polymorphic loci in four populations of milkfish, Chanos chanos. Sample size for each population is 100 and $X^{2}=$ values of Chi-Square test for goodness of fit.

\begin{tabular}{|c|c|c|c|c|c|}
\hline \multirow{2}{*}{ Locus } & \multirow{2}{*}{ Allele } & \multicolumn{4}{|c|}{ Population } \\
\hline & & Aceh & East Java & Bali & South Sulawesi \\
\hline \multirow[t]{4}{*}{ Adh } & -40 & 0.245 & 0.205 & 0.240 & 0.275 \\
\hline & -100 & 0.505 & 0.530 & 0.510 & 0.455 \\
\hline & -140 & 0.250 & 0.265 & 0.250 & 0.270 \\
\hline & $X^{2}$ & 1.44 & 2.23 & 1.63 & 1.20 \\
\hline \multirow[t]{3}{*}{ Aat-1 } & -100 & 0.945 & 0.990 & 0.985 & 1.000 \\
\hline & -150 & 0.055 & 0.010 & 0.015 & 0 \\
\hline & $X^{2}$ & 0.10 & 0.01 & 0.01 & 0 \\
\hline \multirow[t]{3}{*}{ Est-1 } & 100 & 0.860 & 0.920 & 0.915 & 0.925 \\
\hline & 90 & 0.140 & 0.080 & 0.085 & 0.075 \\
\hline & $X^{2}$ & 0.02 & 0.04 & 0.01 & 0.04 \\
\hline \multirow[t]{4}{*}{ Est-2 } & 100 & 0.830 & 0.870 & 0.890 & 0.945 \\
\hline & 75 & 0.150 & 0.120 & 0.100 & 0.025 \\
\hline & 50 & 0.020 & 0.010 & 0.010 & 0.030 \\
\hline & $X^{2}$ & 0.12 & 0.40 & 0.54 & 0.32 \\
\hline \multirow[t]{3}{*}{$\alpha$-Gpd } & 130 & 0.090 & 0 & 0. & 0.010 \\
\hline & 100 & 0.190 & 1.000 & 1.000 & 0.990 \\
\hline & $X^{2}$ & 0.01 & 0 & 0 & 0 \\
\hline \multirow[t]{6}{*}{ Gpi-1 } & 150 & 0.020 & 0.030 & 0.015 & 0.040 \\
\hline & 125 & 0.190 & 0.230 & 0.225 & 0.295 \\
\hline & 100 & 0.450 & 0.540 & 0.555 & 0.445 \\
\hline & 75 & 0.280 & 0.150 & 0.155 & 0.160 \\
\hline & 50 & 0.060 & 0.050 & 0.050 & 0.060 \\
\hline & $X^{2}$ & 2.12 & 3.72 & 3. 28 & 1.80 \\
\hline \multirow{4}{*}{ Gpi-2 } & -50 & 0.015 & 0 & 0 & 0.015 \\
\hline & -100 & 0.975 & 0.990 & 1 & 0.985 \\
\hline & -150 & 0.010 & 0.010 & 0 & 0 \\
\hline & $X^{2}$ & 0.22 & 0.10 & 0 & 0.01 \\
\hline \multirow[t]{4}{*}{ Idh-1 } & 125 & 0.025 & 0 & 0 & 0.020 \\
\hline & 100 & 0.945 & 0.980 & 0.980 & 0.960 \\
\hline & 75 & 0.030 & 0.020 & 0.020 & 0.020 \\
\hline & $X^{2}$ & 0.28 & 0.24 & 0.24 & 0.11 \\
\hline \multirow[t]{3}{*}{ Ldh-1 } & 150 & 0.010 & 0 & 0 & 0 \\
\hline & 100 & 0.990 & 1 & 1 & 1 \\
\hline & $X^{2}$ & 0.01 & 0 & 0 & 0 \\
\hline \multirow[t]{3}{*}{ Mdh-1 } & 100 & 0.970 & 1 & 1 & 0.940 \\
\hline & 70 & 0.030 & 0 & 0 & 0.060 \\
\hline & $X^{2}$ & 0 & 0 & 0 & 0.01 \\
\hline \multirow[t]{4}{*}{ 6-Pgd } & 120 & 0.005 & 0.005 & 0.020 & 0.030 \\
\hline & 100 & 0.840 & 0.815 & 0.800 & 0.780 \\
\hline & 50 & 0.155 & 0.180 & 0.180 & 0.190 \\
\hline & $X^{2}$ & 1.16 & 2.60 & 1.12 & 2.48 \\
\hline \multirow[t]{3}{*}{ Pgm-2 } & -100 & 0.135 & 0.080 & 0.090 & 0.025 \\
\hline & -120 & 0.865 & 0.920 & 0.910 & 0.975 \\
\hline & $X^{2}$ & 1.83 & 0.48 & 0.90 & 0.56 \\
\hline
\end{tabular}

\section{Data Analysis}

A log-likelihood ratio for goodness of fit (Sokal \& Rohlf, 1981) was used to compared observed frequencies of phenotypic classes with those expected under Hardy-Weinberg equilibrium. A locus was considered to be polymorphic if the most common allele was equal or less than 0.99 
( $1 \%$ ) at one or more samples. Heterozygosity was defined by $\mathrm{h}=1-\mathrm{pi}^{2}$, where $\mathrm{pi}^{2}$ is the frequency of the $\mathrm{i}$-th allele. $\underline{\mathrm{H}}$ is the average of $\underline{h}$ over loci including monomorphic. Observed main allele frequencies at polymorphic loci were compared a cross all localities using heterogeneity test $\left(X^{2}\right)$. The genetic distance among populations were calculated using Nei (1972) formula and dendrogram was constructed from the matrix genetic distance using Unweighted Pair Group Method with Arithmetic Average (UPGMA) (Sneath \& Sokal, 1973)

\section{RESULTS}

Enzymes and protein examined, locus detected, tissues assayed and buffer systems giving the clearest resolution are presented in Table 1 . Fourteen enzymes and one protein (SP) ecoded by 29 loci were electrophoretically detected. Using $0.99(1 \%)$ criterion of polymorphism, 12 loci (Adh, Aat-1, Est-1, Est-2, -Gpd, Gpi-1, Gpi-2, Idh-1, Ldh1, Mdh-1, 6-Pgd and Pgm-2 ) were considered polymorphic in at least one population sample (Tables 1, 2)

Zymogram patterns for polymorphic enzyme systems are shown in Figure 1. Among polymorphic loci, the number of alleles observed ranged from 2 for Est-1 to 5 for Gpi-1. Allele frequencies of twelve polymorphic loci are presented in Table 2. Goodness of fit to HardyWeinberg equilibrium was tested for all polymorphic loci. The genotypic distribution observed at each polymorphic locus in all samples were found to be in agreement with that expected from the Hardy-Weinberg equilibrium, (Table 2). The higher levels of genetic variability are found at Adh, Est-1, Est-2, Gpi-1, 6-Pgd and Pgm-2 loci
(Table 2) and will be used as genetic markers in breeding studies

Summary of genetic variability in four populations of milkfish which were indicated by the proportion of polymorphic loci the number of alleles per locus and the average observed ( $\mathrm{Ho}$ ) and expected $(\mathrm{He})$ heterozygosities are presented in Table 3. The proportion of polymorphic loci ranged from 0.276 to 0.414 with an average of 0.336 . The average number of alleles per locus ranged from 1.482 to 1.689 with an average of 1.577. The observed heterozygosity (Ho) ranged from 0.062 to 0.074 with an average of 0.068 and average expected value $\mathrm{He}$ ranged of 0.062 to 0.073 with an average of 0.068 . The ratio of $\mathrm{Ho} / \mathrm{He}$ ranged of 1.000 to 1.105 with an average of 1.007 . Since this value has nearly unity, there is no indication of inbreeding in these milkfish populations. In general, the value of genetic variability for Aceh sample was slightly higher than those of other samples.

The allele frequency differences among populations were tested by Chi-Square for heterozygosity at main allele of polymorphic loci (Table 4). In some loci, allelic differences between two populations were significant such as in main alleles-100 of Est-1 and -Gpd loci for Aceh vs other populations, Adh and Est-2 for South Sulawesi vs other populations, also Adh, Est-1, Est-2, -Gpd and Pgm-2 for Aceh vs South Sulawesi, while no allellic differences found between Bali and E. Java populations (Table 4).

This allelic differences indicated that these populations is independence to one and others, except for Bali and E. Java populations should be considered as a single population.

Table 3. Summary of genetic variability in milkfish populations based on electrophoretic analysis of 29 loci and 1\% criterion of polymorphism

\begin{tabular}{lcccc}
\hline & \multicolumn{3}{c}{ Population } \\
\cline { 2 - 5 } & Aceh & East Java & Bali & South Sulawesi \\
\hline Number of samples examined & 100 & 100 & 100 & 100 \\
Number of loci examined & 29 & 29 & 29 & 29 \\
Number of polymophic loci & 12 & 9 & 8 & 10 \\
Proportion of polymorphic loci & 0.414 & 0.310 & 0.276 & 0.345 \\
Number of allele per locus & 1.689 & 1.517 & 1.482 & 1.621 \\
Heterozygosity: & & & & 0.070 \\
Observed (Ho) & 0.074 & 0.066 & 0.062 & 0.070 \\
Expected (He) & 0.073 & 0.065 & 0.062 & 1.000 \\
Ho/He & 1.013 & 1.015 & 1.000 & \\
\hline
\end{tabular}


Table 4. Chi-Square $\left(X^{2}\right)$ values of heterogeneity test for each main allele at polymorphic locus between populations

\begin{tabular}{|c|c|c|c|c|c|c|}
\hline \multirow[b]{2}{*}{ Locus $(d . f=1)$} & \multicolumn{6}{|c|}{ Populations } \\
\hline & $\begin{array}{c}\text { Aceh } \\
\text { vs } \\
\text { E. Java }\end{array}$ & $\begin{array}{c}\text { Aceh } \\
\text { vs } \\
\text { Bali }\end{array}$ & $\begin{array}{c}\text { Aceh } \\
\text { vs } \\
\text { S. Sulaw esi } \\
\end{array}$ & $\begin{array}{c}\text { E. Java } \\
\text { vs } \\
\text { Bali } \\
\end{array}$ & $\begin{array}{c}\begin{array}{c}\text { E. Java } \\
\text { vs } \\
\text { S. Sulawesi }\end{array} \\
\end{array}$ & $\begin{array}{c}\text { Bali } \\
\text { vs } \\
\text { S. Sulawesi } \\
\end{array}$ \\
\hline Adh & 0.38 & 0.91 & $4.36^{*}$ & 0.28 & $4.42^{\star}$ & $4.40^{*}$ \\
\hline Aat. 1 & 0.83 & 0.79 & 1.12 & 0.00 & 0.01 & 0.01 \\
\hline Est- 1 & $4.31^{*}$ & $4.18^{*}$ & $4.53^{\star}$ & 0.00 & 0.01 & 0.01 \\
\hline Est. 2 & 1.18 & 1.26 & $5.84^{\star}$ & 0.62 & $4.43^{*}$ & $6.34^{*}$ \\
\hline$\alpha \cdot G p d$ & $5.64^{*}$ & $5.64^{*}$ & $4.38^{*}$ & 0.00 & 0.11 & 0.10 \\
\hline Gpi-1 & $5.62^{*}$ & $6.18^{\star}$ & 0.01 & 0.00 & $5.95^{*}$ & $6.01^{\star}$ \\
\hline Gpi-2 & 0.12 & 0.02 & 0.14 & 0.15 & 0.11 & 0.11 \\
\hline Idh- 1 & 1.18 & 1.18 & 0.38 & 0.00 & 0.12 & 0.12 \\
\hline Ldh-1 & 0.66 & 0.06 & 0.06 & 0.00 & 0.00 & 0.00 \\
\hline Mdh-1 & 0.44 & 0.44 & 0.44 & 0.00 & 1.89 & 1.89 \\
\hline 6.Pgd & 0.22 & 0.51 & 1.36 & 0.13 & 0.12 & 0.12 \\
\hline Pgm-2 & 1.10 & 1.28 & $6.38^{*}$ & 0.98 & 0.98 & 0.96 \\
\hline
\end{tabular}

The values of Nei's genetic distance (D) between each pair of populations ranged between 0.00028 to 0.00270 with an average of 0.00155 (Table 5). To summarize the relations among populations, a UPGMA dendrogram was conducted on the basis of a matrix at Nei s genetic distance (Fig. 2). The UPGMA cluster analysis of genetic distance revealed very clear relationship between genetic distance and geographic distance. The result showed three main groupings of populations that were Aceh, S. Sulawesi with Bali and $\mathrm{E}$. Java considered as one population

\section{DISCUSSION}

The best estimated of genetic variation in natural population is the average heterozygosity (H) (Allendorf \& Utter, 1979). The mean observed heterozygosity $(\mathrm{H})$ of four populations for milkfish in the present study is 0.068 . Winans (1980) compiled data for 82 species of fish and calculated a mean heterosigosity of 0.478 . Sumantadinata and Taniguchi (1982) found the average heterozygosity of 0.066 for black sea bream, Taniguchi \& Sugama (1990) estimated heterozygosity of red sea bream at 0.058 and Fujio (1981) calculated mean heterozygosity for 103 species of marine fish at 0.053 . Thus, the heterozygosity of milkfish from the wild population is slightly higher than other marine fish.

The main interest of the present study was to search if there is any genetic differentiation among populations of milkfish within Indonesia. The heterogeneity test revealed statistically significant differences in allele frequencies between pairs of populations except for Bali and E. Java.

According to Grant et al. (1987), the allele frequency differences between populations of marine fishes resulted from the action of three forces, i.e. migration, random genetic drift and natural selection. They also suggested that little

Table 5. Matrix Nei's genetic distance between every pair of four populations of milkfish based on 29 loci

\begin{tabular}{ccccc}
\hline & Aceh & East Java & Bali & South Sulawesi \\
\hline Aceh & - & 0.00178 & 0.00196 & 0.00270 \\
East Java & - & - & 0.00028 & 0.00131 \\
Bali & - & - & - & 0.00126 \\
S. Sulawesi & - & - & - & - \\
\hline
\end{tabular}



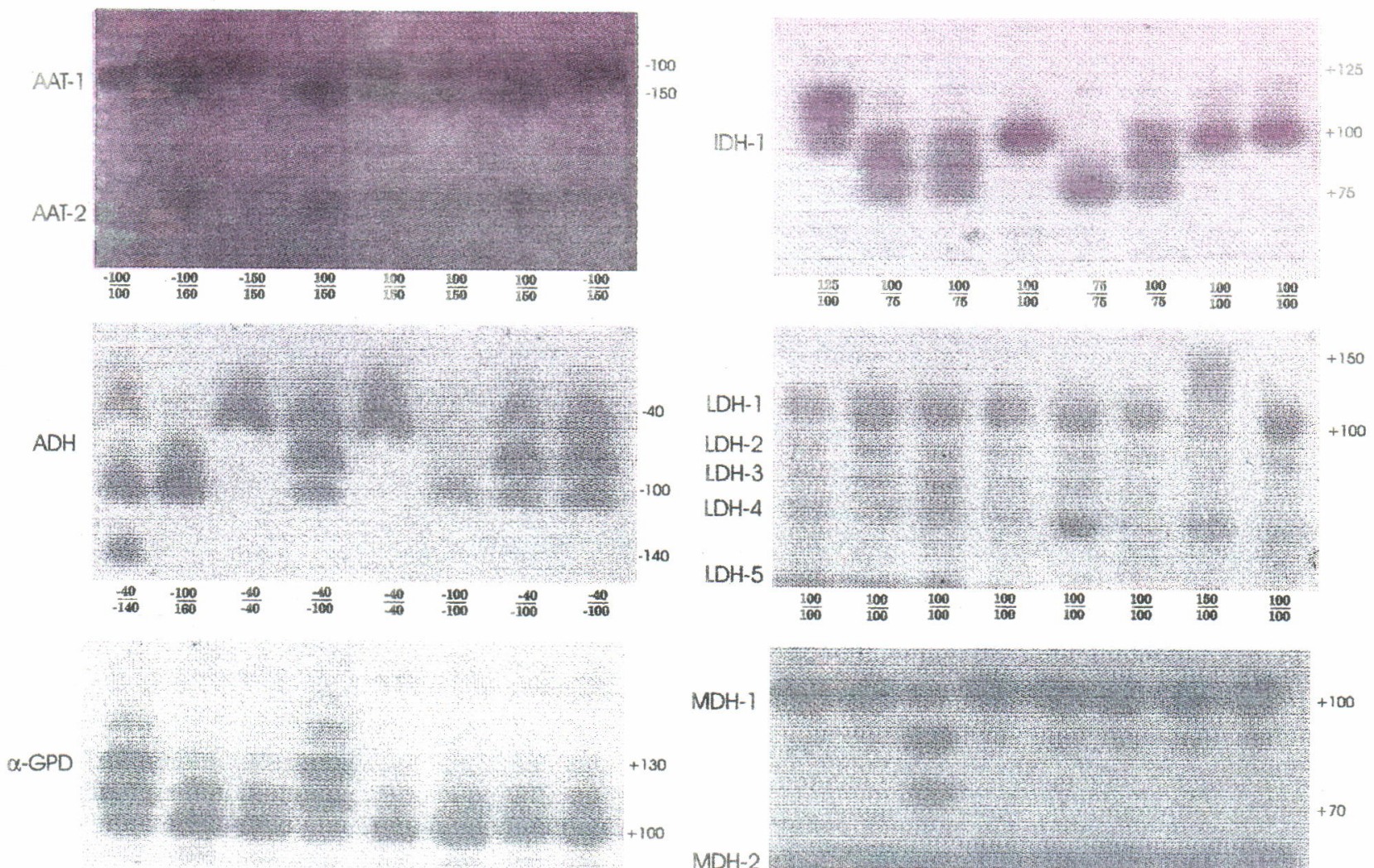

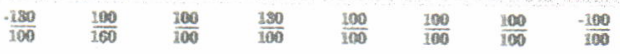
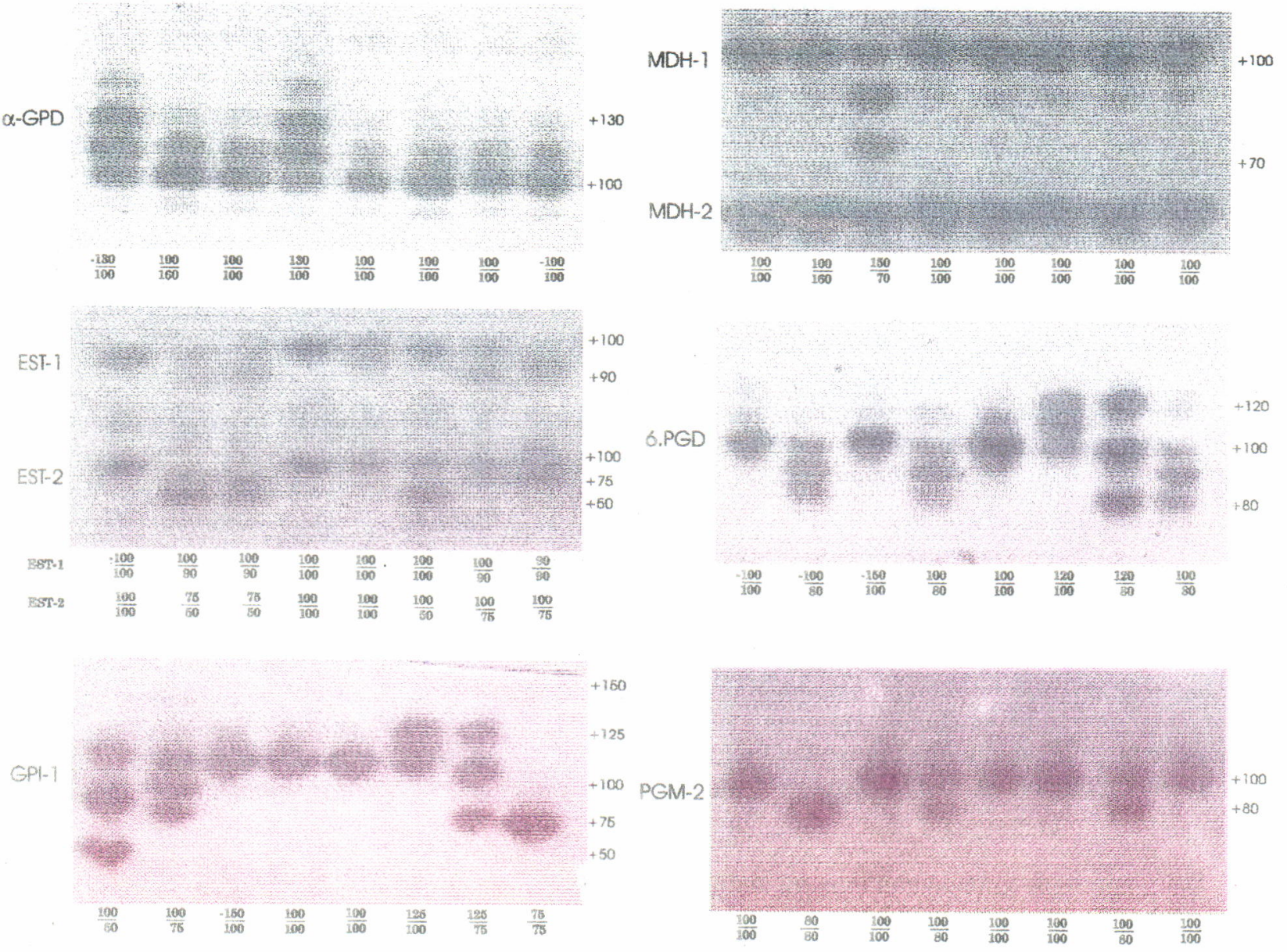

Figure 1. Zymogram of polymorphic loci in milkfish 
or no genetic differentiation would be expected between populations of marine fishes due to high potential for gene flow between populations, the lack of genetic drift in a very large population or because combination of these mechanisms. These patterns were observed in several marine fishes such as Walleye pollock (Grant \& Utter, 1980), Pacific herring (Clupea pallasi) and Atlantic herring Clupea horengus (Grant, 1984; Grant \& Utter, 1984 and Ryman et al., 1984) and Atlantic cod Gobus morhua (Mork et al., 1985).

The genetic differentiation observed between natural populations of milkfish in the present study could be explained by the lack of migration or gene flow particularly between populations of Aceh and S. Sulawesi which were isolated from each other due to geographical distance. Consequently no genetic differentiation observed between Bali and $\mathrm{E}$. Java populations indicated free gene flow of the two populations due to very close geographic distance.

The average genetic distance among populations is 0.00155 . This value is typical of divergence between conspecific populations. The UPGMA cluster analysis of genetic distance formed three geographical groups (group Bali and E. Java, Aceh and S. Sulawesi), and very clear relationship between the genetic distance and geographic distance (Figure 2).

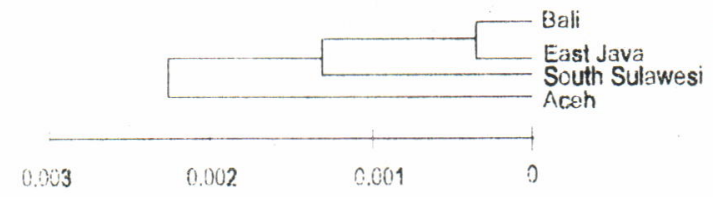

Figure 2. Dendrogram drawn from the genetic distance between every pair of populations of milkfish

The values of genetic distance and the highly significant difference in allelic frequencies among populations, suggested the independence of the subpopulation of Aceh from others, except Bali and E. Java was considered as one population. This can be understandable since Aceh is geographically much farer from the other populations. It was concluded that the natural population of milkfish in Indonesia could be divided into 3 geographical groups located in Western part of Indonesia (Aceh), Midle part of Indonesia (Bali and Java) and Eastern part of Indonesia (South Sulawesi).

\section{ACKNOWLEDGEMENT}

We wish to express thanks to Dr. John Benzie, Australian Institute of Marine Science for his advice.

\section{REFERENCES}

Agenese. J. F., Oteme. Z. J. and Gilles, S. 1995 Effect of domestication on genetic variability, fertility, survival and growth rate in a tropical siluriform: Iheterobranchius longifilis Valenciennes 1840 . Aquaculture 131: 197-204.

Allendorf, F. W. and Utter. F.M. 1979. Populations genetics. In Hour W. S., Randall D.J. and Breet J.R. (eds.). Fish Physiology Vol. 8. Academic Press. New York. p 407.454.

Fujio, Y. 1981. Genetic variability of biochemical traits in fish population. Kaiyo Kagaku 13(1): 35-41.

Grant, W.S. and Utter, F.M. 1984. Biochemical populations genetics of Pacific herring Clupec pallasi. Can. J. Fish. Aquaculture Sci. 41: 856-864.

Grant, W.S. 1984. Population biochemical genetics of Atlantic herring Clupea haregus. Copeia 84: 357. 346

Grant, W.S., Teel, D.J. and Schmitt, C. 1984. Biochemical population genetics of Pacific halibut (Hippoglossus sterolepsis) and comparison with Atlantic halibut (H. hippoglossus). Canada. .J. Fish. Aquaculture Sci. 41: 1083-1088.

Grant, W. S., Zhang, C.I., Kobayashi, T. and Sthal, G. 1987. Lack of genetic structure discretion in Pacific cod (Gäadus macrocephalus). Canada. J. Fish. Arquaculture Sci. 44: 490-498.

Goudie, C.A., Liu Q., Simco, B.A. and Davis, K.B. 1995. Genetic relationship of growth, sex and glucophosphate isomerase-B phenotypes in channel catfish (Ictchlurus punctutus). Aquaculture 138: 119-124.

Macaranas, Y. M., Pante, M.J.R. and Benitez, L.V. 1990. Heterogeneity in Philippine milkfish populations. In: Hirano R. and Hanyu I. (eds.). The second Asian Fisheries Forum. Asian Fish. Soc. Manila Philippines. p 477-480.

Mark, J., Rayman, N., Stahl, G., Utter, F. and Sundnes, G. 1985. Genetic variation in Atlantic cod (Gadus marhua) throughout its range. ('an. .J. Fish. Aquaculture Sci. 42: 1580-1587

Nei, M. 1972. Genetic distance between populations. Am. Nat. 106: 283-292.

Rayman, N., Lagercrantz, U., Anderson, L., Chakraborty, R. and Rosenberg, R. 1984. Lack of correspondence between genetic and morphologic variability patterns in Atlantic herring (Clupea harengus). Heredity 53: 687-704

Shaw, C.R. and Prasad, R. 1970. Starch gel electrophoresis of enzymes a compilation of recipes. Biochem. Gen. 4: 297-321. 


\section{K. Sugama and A. Prijono}

Shaklee, J.B., Morizot, A.D.C. and Whitt, G.S. 1990 Gene nomenclature for protein coding loci in fish. Trans. Am. Fish. Soc. 119: 2-15.

Sneath, P.H. and Sokal, R.R. 1973. Numerical Taxonomy. Freeman and Co. Sun Francisco, Ca. 859 $\mathrm{pp}$.

Sokal, R.R. and Rohlf, F.J. 1981. Biometry. Freeman. San Francisco. Ca. 859 pp.

Sugama, K., Aslianti, T. and Prijono, A. 1997. Perbenihan Bandeng. Profil Badan Litbang Pertanian. Jakarta. $10 \mathrm{pp}$.

Sugama, K., Taniguchi, N. and Seki, S. 1992. Survival growth and gonad development of triploid red sea bream, Aquaculture Fish. Man. 23: 149-159.

Sugama, K. Haryanti, K. and Cholik, F. 1996. Biochemical genetics of tiger shrimp Penapus. monodon: Description electrophoresis detectable loci. Indon. Fish. Res, J. II(1): 19.28

Sumantadinata, K. and Taniguchi, N. 1982. Biochemical genetic variations in black sea bream. Bull. Jap. Soc. Sci. Fish. 48: 143-149.

Taniguchi, N., Sumantadinata, K. and Iyama, S. 1983. Genetic change in the first and second generations of hatchery stock of Black Sea Bream. Aquaculture. 35: $309-320$

Taniguchi, N. and Sugama, K. 1990. Genetic variation and populations structure of red sea bream in the coastal waters of Japan and in the East China Sea. Bull. Jap. Soc. Sci. Fish. 56: 1069-1077.

Wenans. G.A. 1980. Geographic variation in the milkfish (hanos chanos. Biochem. Ev. 34: 558-574. 